\title{
CHEMOSPHERE
}

PERGAMON

\section{Toxicity and bioaccumulation of copper in three green microalgal species}

\author{
Hai Yan ${ }^{a, *}$, Gang Pan ${ }^{\text {a,b }}$ \\ a State Key Laboratory of Environmental Aquatic Chemistry, Research Center for Eco-environmental Sciences, \\ Chinese Academy of Sciences, P.O. Box 2871, Beijing 100085, China \\ ${ }^{\mathrm{b}}$ Eco-environmental Chemistry Laboratory, Qingdao Institute of Chemical Technology, Qingdao 266042, China
}

Received 3 July 2001; received in revised form 6 May 2002; accepted 3 June 2002

\begin{abstract}
The effective concentrations of copper on the inhibition of the growth of Scenedesmus obliquus, Chlorella pyrenoidosa and Closterium lunula at $96 \mathrm{~h}$ (96 h EC50) were determined to be 50, 68 and $200 \mu \mathrm{g} / \mathrm{l}$, respectively. The low initial bioaccumulation of $\mathrm{Cu}$ by $\mathrm{C}$. lunula was found to be responsible for its tolerance to $\mathrm{Cu}$. The amount of $\mathrm{Cu}$ accumulated by all three microalgae reached the maximum value and decreased quickly after the peak followed by a slow decrease over the next $6 \mathrm{~d}$. Bioaccumulation of $\mathrm{Cu}$ by $\mathrm{C}$. lunula was directly proportional to the initial $\mathrm{Cu}$ concentration. After reaching the first peak after $1 \mathrm{~d}$, the bioconcentration factor of $\mathrm{Cu}$ by microalgae declined to its minimum value during the exponential growth phase but increased in the stationary growth phase again. This indicates that desorption of $\mathrm{Cu}$ from microalgae was higher during the exponential growth phase but lower in the stationary growth phase. Smaller microalgae with low $96 \mathrm{~h}$ EC50 values are more efficient in removing $\mathrm{Cu}$ from wastewater.
\end{abstract}

(c) 2002 Elsevier Science Ltd. All rights reserved.

Keywords: Chlorella pyrenoidosa; Scenedesmus obliquus; Closterium lunula; Copper; Metal; Bioaccumulation; Inhibition; Toxicity

\section{Introduction}

Copper is one of the most important and potentially toxic metallic pollutants (Chang and Sibley, 1993). The toxicity of copper is mainly related to free ions (Knauer et al., 1997) and its sensitivity varies among microalgae (Soldo and Behra, 2000). Toxic metals may affect microalgal photosynthesis, growth, enzyme activity and respiration. The effective concentration of heavy metal that inhibits $50 \%$ microalgal growth at $96 \mathrm{~h}$ (96 h EC50) is widely used as an index of toxicity (Hornstrom, 1990). One mechanism of tolerance by algae is physiological exclusion of metal ions due to reduced cell membrane permeability (Brown et al., 1988). Internal metal im-

\footnotetext{
${ }^{*}$ Corresponding author. Tel.: +86-1062-943436; fax: +861062-923543.

E-mail address: haiyan@mail.rcees.ac.cn (H. Yan).
}

mobilization by the formation of copper bodies can also occur (Nassiri et al., 1997). Binding to organic complexes, especially cell exudates, is another possible mechanism regulating the detoxification of metal ions (Xue et al., 1988; Xue and Sigg, 1990; Rijstenbil et al., 1994; Gerringa et al., 1995). It has been reported that microalgal production of glutathione, thiols or superoxide dismutase activity (SOD) can be stimulated by copper, which may also be a defense mechanism against copper toxicity (Rijstenbil et al., 1994, 1998a,b; Rijstenbil and Wijnholds, 1996; Okamoto and Colepicolo, 1998; Leal et al., 1999).

Sorption of heavy metals from aqueous solution by microalgae has attracted much attention for the wastewater treatment, which can often reduce the concentration of heavy metals greatly. Sorption capacities of marine algal biomass for cadmium, copper and lead were found to be greater than those of other types of biomass (Yu et al., 1999). Knauer et al. (1997) observed 
that bioaccumulation of copper by microalgae consisted of an initial fast passive adsorption process followed by a slow active intracellular uptake. The first fast step is reversible and contains the processes of adsorption, ion exchange, coordination, complexation, chelation and microprecipitation. The second slow uptake is often irreversible and can be due to a number of mechanisms including covalent bonding, surface precipitation, redox reactions or most often, diffusion into the cell interior and binding to proteins and other intracellular sites (Kuyucak and Volesky, 1989). Hassall (1962) reported that dead cells can uptake more metals than living cells, indicating a possible desorption ability of metals by the living cells.

Although both the toxicity and the bioaccumulation of copper in microalgae have been extensively studied, little information is available on the relationships between the two. Here, the inhibition effects of copper on the growth of three microalgal species were evaluated and the long-term bioaccumulation processes of copper in microalgae were investigated. It was found that the less initial bioaccumulation amount of $\mathrm{Cu}$ by Closterium lunula was responsible for its strong tolerance to $\mathrm{Cu}$, which was important for both evaluation of water quality and treatment of heavy metal polluted wastewater.

\section{Materials and methods}

\subsection{Chemicals and microalgae}

Analytical grade of $\mathrm{CuCl}_{2}$ was used in the experiments. Chlorella pyrenoidosa, Scenedesmus obliquus and C. lunula were bought from the Institute of Hydrobiology, Academia Sinica, China.

\subsection{Medium}

The culture medium consisted of $0.200 \mathrm{~g}$ of $\left(\mathrm{NH}_{4}\right)_{2} \mathrm{SO}_{4}, 0.030 \mathrm{~g}$ of superphosphate, $0.080 \mathrm{~g}$ of $\mathrm{MgSO}_{4}, 0.100 \mathrm{~g}$ of $\mathrm{NaHCO}_{3}, 0.025 \mathrm{~g}$ of $\mathrm{KCl}, 0.15 \mathrm{ml}$ of $1 \%(\mathrm{w} / \mathrm{v}) \mathrm{FeCl}_{3} \cdot 6 \mathrm{H}_{2} \mathrm{O}$ solution and $1000 \mathrm{ml}$ of distilled water. Initial $\mathrm{pH}$ of the medium was adjusted to 7.0 using $1 \mathrm{~N} \mathrm{HCl}$ solution. The medium and all experimental utensils used were sterilized at $124^{\circ} \mathrm{C}$ for $20 \mathrm{~min}$.

\subsection{Culture condition}

For studies of both toxicity and bioaccumulation, microalgae were grown in a $100 \mathrm{ml}$ flask containing 30 $\mathrm{ml}$ inoculums at $24{ }^{\circ} \mathrm{C}$ with a light intensity of 40 $\mu \mathrm{mol} \mathrm{m} \mathrm{m}^{-2} \mathrm{~s}^{-1}$ in a $12-12 \mathrm{~h}$ light-dark circle. A spectrophotometer was used to measure the optical density of culture solution at $650 \mathrm{~nm}$ (OD650 nm) to express microalgal biomass and the initial OD650 nm was pre- pared as $0.010 . \mathrm{Cu}$ stock solution of $500 \mathrm{mg} / \mathrm{l}$ was prepared using sterilized distilled water, which was further diluted to different initial levels of $\mathrm{Cu}$ using the medium. The experiment was conducted in triplicate. The data presented here were the average values of three parallel samples and their relative standard deviations were less than $10 \%$.

\subsection{Calculation of 96 h EC50}

$\mathrm{Cu}$ toxicity expressed as the $96 \mathrm{~h}$ EC50 was calculated by a linear regression between probability unit (PU) and $\log$ (initial $\mathrm{Cu}$ concentration, $\mu \mathrm{g} / \mathrm{l}$ ). PU was obtained using a relationship table between PU and the reaction ratio between the $\mathrm{OD} 650 \mathrm{~nm}$ when $\mathrm{Cu}$ is added and the OD650 $\mathrm{nm}$ when $\mathrm{Cu}$ is not added at $96 \mathrm{~h}$ (Zhou and Zhang, 1989). Ninety hour EC50 is calculated by a linear regression dose reaction equation when $\mathrm{PU}$ is set to 5 . The dose response equation was $X^{2}$ tested with $95 \%$ confidence.

\subsection{Measurement of dry weight concentration of micro- algae}

Dry weight of microalgae was determined with a digital balance after the cells filtered on a $0.22 \mu \mathrm{m}$ membrane were dried at $103{ }^{\circ} \mathrm{C}$ for $2 \mathrm{~h}$. Good linear relationships between dry weight concentration (DWC) and OD650 nm were obtained. For C. pyrenoidosa, $\operatorname{DWC}(\mathrm{mg} / \mathrm{l})=-1.94+343.46 \times$ OD650 nm $(r=0.9990)$. For $S$. obliquus, DWC $(\mathrm{mg} / \mathrm{l})=-3.88+617.97 \times \mathrm{OD} 650$ $\mathrm{nm}(r=0.9920)$. For $C$. lunula, $\mathrm{DWC}(\mathrm{mg} / \mathrm{l})=0.75+$ $495.67 \times$ OD650 nm $(r=0.9997)$. These linear regression equations were used to estimate the DWC in culture solution.

\subsection{Measurement of $\mathrm{Cu}$, bioaccumulation and bioconcen- tration factor}

The standard analytical method recommended by the Chinese EPA (Chinese EPA, 1989) was used to measure the total ambient $\mathrm{Cu}$ concentration in the medium. Nitric acid of $5 \mathrm{ml}$ was added to a filtered medium of $30 \mathrm{ml}$ (0.22 $\mu \mathrm{m}$ membrane), which was heated to $100{ }^{\circ} \mathrm{C}$ for about $5 \mathrm{~h}$, and then distilled water was added to keep the volume of $30 \mathrm{ml}$ constant. Five milliliter of $0.2 \%(\mathrm{w} / \mathrm{v})$ sodium diethyldithiocarbamate solution was added to the solution and the $\mathrm{pH}$ of medium was adjusted to 8.5 using $\mathrm{NH}_{3} \mathrm{H}_{2} \mathrm{O}$. The purple complex of $\mathrm{Cu}$ was formed in the presence of cresyl red, which was extracted by $5 \mathrm{ml}$ of tetrachlorated carbon. The absorbance of extracting solution was measured at the wavelength of $440 \mathrm{~nm}$ with a spectrophotometer and the limit of detection was 2 $\mu \mathrm{g} / \mathrm{l}$ of $\mathrm{Cu}$. 
Accumulation amount of $\mathrm{Cu}$ was calculated as the difference between the initial and final $\mathrm{Cu}$ concentrations at different time intervals in the solution, which included $\mathrm{Cu}$ bound in cell-wall adhering precipitate plus accumulated $\mathrm{Cu}$ in the cells. The bioconcentration factor (BCF) was calculated as the ratio between the bioaccumulation amount of $\mathrm{Cu}(\mu \mathrm{g} / \mathrm{mg}$-dry wet) and the $\mathrm{Cu}$ concentration in solution.

\subsection{Controls}

Controls consisted of $100 \mu \mathrm{g} / \mathrm{l} \mathrm{Cu}$ in the medium without algae. All the other experimental conditions are the same as those of algae. The change of total $\mathrm{Cu}$ concentration was less than $3 \%$ in the period of $6 \mathrm{~d}$.

\section{Results}

\subsection{Toxicity of $\mathrm{Cu}$}

In the absence of added $\mathrm{Cu}$, microalgal biomass expressed as OD650 $\mathrm{nm}$ at $96 \mathrm{~h}$ was in the order of C. pyrenoidosa $>$ C. lunula $>$ S. obliquus (Fig. 1). The biomass decreased as the initial $\mathrm{Cu}$ concentration increased (Fig. 1). For C. lunula, OD650 nm decreased less than the other two algae (Fig. 1). The corresponding linear dose response equations between $\mathrm{PU}$ and $\log (\mathrm{Cu}$ concentration, $\mu \mathrm{g} / \mathrm{l}$ ) were established in Fig. 2. Based on the regression equations, the $96 \mathrm{~h}$ EC50 for the inhibition of the growth of S. obliquus, C. pyrenoidosa and C. lunula

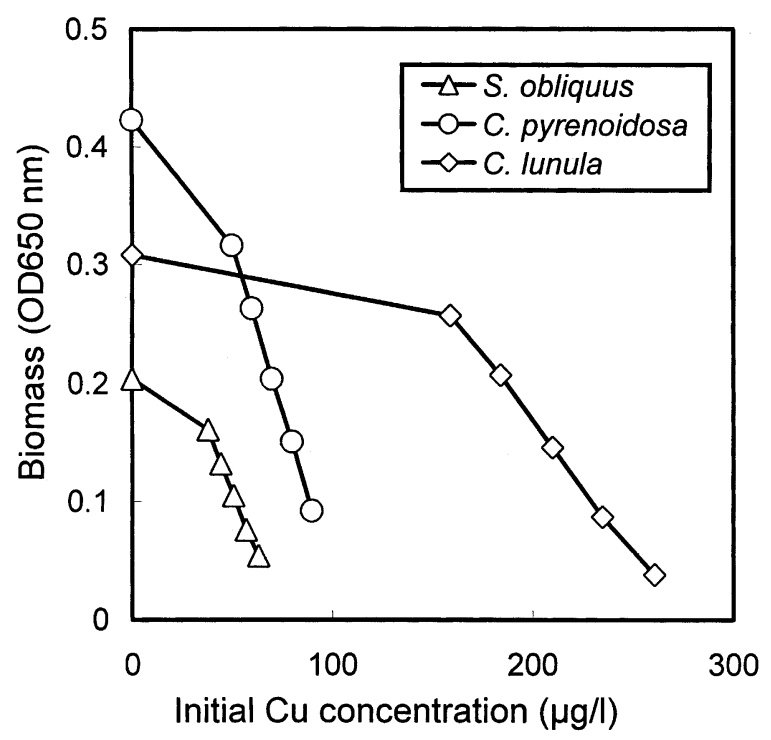

Fig. 1. Toxic effect of copper on the inhibition of microalgal growth at $96 \mathrm{~h}$. OD650 nm was used to express microalgal biomass and initial OD650 $\mathrm{nm}$ was set to 0.010 .

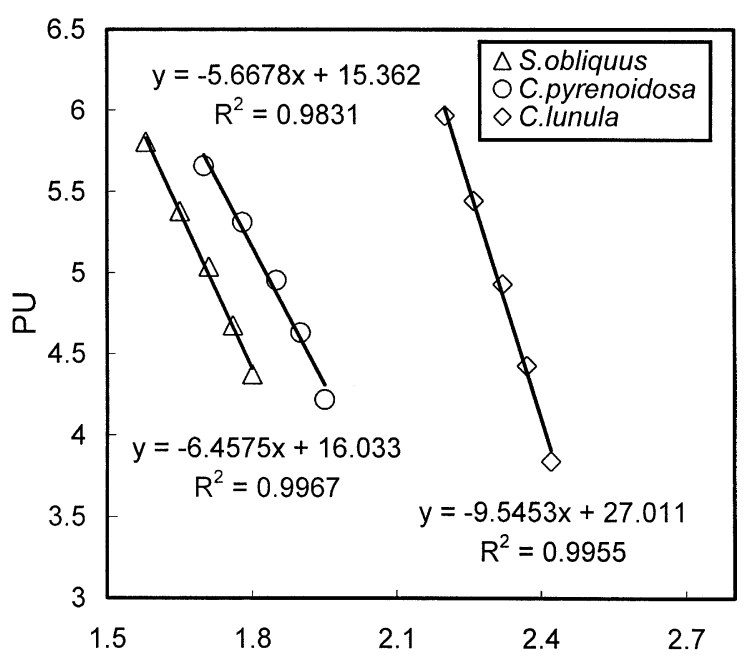

Log (initial Cu level, $\mu \mathrm{g} / \mathrm{l}$ )

Fig. 2. Linear regression of dose response equation between PU and $\mathrm{Log}$ (initial $\mathrm{Cu}$ concentration, $\mu \mathrm{g} / \mathrm{l}$ ) at $96 \mathrm{~h}$. PU was obtained using a relationship table between PU and reaction ratio that is the ratio between OD650 $\mathrm{nm}$ at different initial $\mathrm{Cu}$ concentrations and OD650 $\mathrm{nm}$ without added $\mathrm{Cu}$.

were calculated to be 50, 68 and $200 \mu \mathrm{g} / \mathrm{l}$, respectively (Fig. 2). C. lunula was far more tolerant to $\mathrm{Cu}$ than the other two algae. The $96 \mathrm{~h}$ EC50 values obtained were tested for significance with the $X^{2}$ test $(\alpha=0.05)$.

\subsection{Growth process of microalgae}

The growth process of microalgae during the 6-d period underwent a lag, exponential and stationary growth phases (Fig. 3). Because of the greatest growth rate of $C$. pyrenoidosa and the greatest sensitivity of $S$. obliquus to $\mathrm{Cu}$, the order of growth was also C. pyrenoidosa $>C$. lunula $>S$. obliquus with an initial $\mathrm{Cu}$ concentration of $50 \mu \mathrm{g} / \mathrm{l}$ (Fig. 3). Growth of S. obliquus was most inhibited and its exponential growth phase was postponed (Fig. 3). When $\mathrm{Cu}$ added was increased from 50 to $200 \mu \mathrm{g} / \mathrm{l}$, the growth of $C$. lunula was also inhibited and the lag growth phase was prolonged (Fig. 3).

\subsection{Removal of $\mathrm{Cu}$ from medium by microalgae}

Concentrations of $\mathrm{Cu}$ remained in the medium were first rapidly and then slowly reduced during the 6-d experimental period (Fig. 4). When initial $\mathrm{Cu}$ concentration was $50 \mu \mathrm{g} / \mathrm{l}, 95 \%, 79 \%$ and $67 \% \mathrm{Cu}$ were removed by $C$. pyrenoidosa, C. lunula and S. obliquus, respectively, after $6 \mathrm{~d}$ of exposure. Removal of $\mathrm{Cu}$ by $C$. lunula from the medium was proportional to the initial $\mathrm{Cu}$ concentration (Fig. 4). 


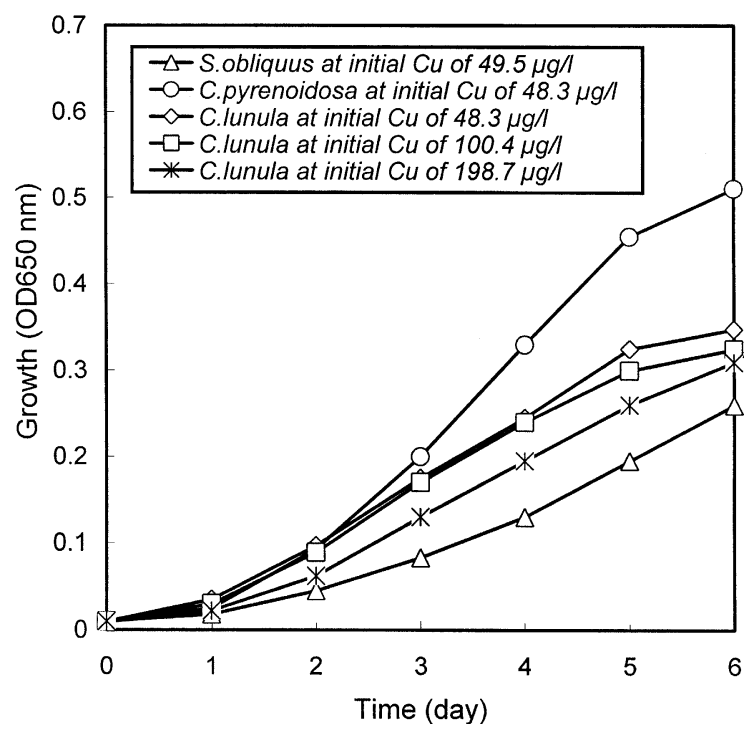

Fig. 3. The growth process of microalgae at different initial levels of $\mathrm{Cu}$.

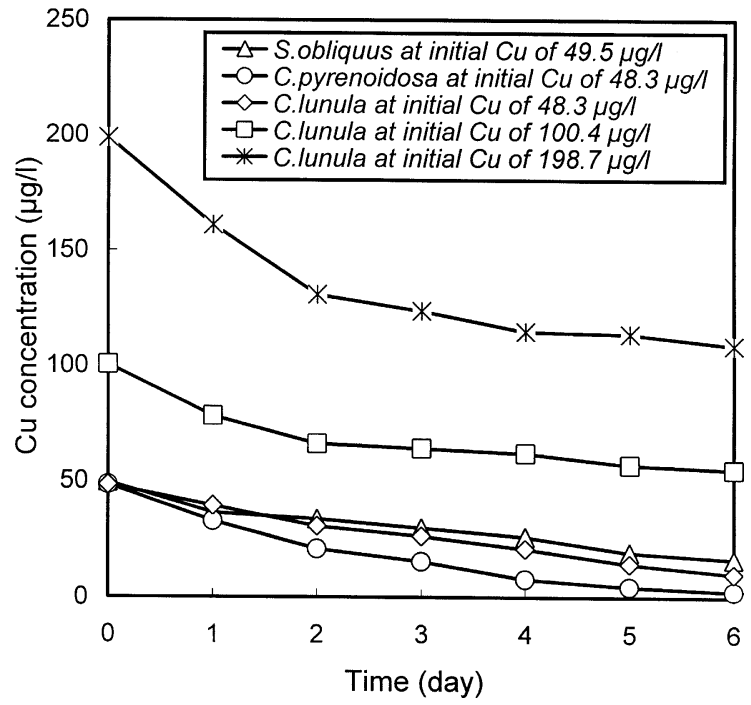

Fig. 4. The removal of $\mathrm{Cu}$ from the medium with the growth of microalgae.

\subsection{Accumulation amount of $\mathrm{Cu}$}

The amount of $\mathrm{Cu}$ accumulated by microalgae reached a maximum after $1 \mathrm{~d}$ but quickly decreased after $2 \mathrm{~d}$ followed by a slow decrease at the next $6 \mathrm{~d}$ (Fig. 5). Accumulation of $\mathrm{Cu}$ by $C$. lunula was much less than those of the other two species. The amount of $\mathrm{Cu}$ accumulated by $C$. lunula was proportional to $\mathrm{Cu}$ concentration in the medium (Fig. 5).

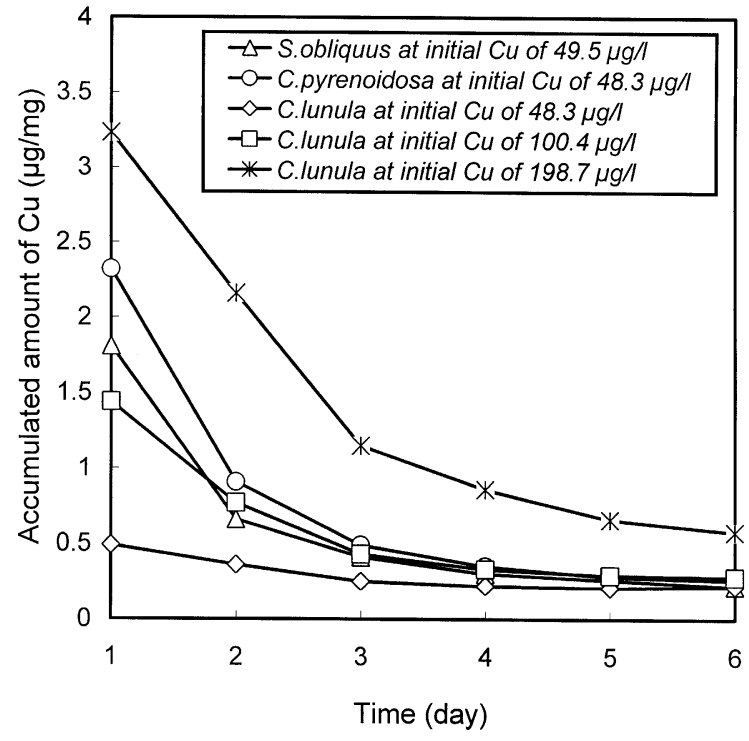

Fig. 5. The change of accumulation amount of $\mathrm{Cu}$ by microalgae. The accumulation amount refers to the $\mathrm{Cu}$ bound in cellwall adhering precipitate plus accumulated $\mathrm{Cu}$ in the cells.

\subsection{Bioconcentration factor of $\mathrm{Cu}$}

BCF reached its first peak after $1 \mathrm{~d}$ and then decreased at the beginning of exponential growth phase (Fig. 6). After $3 \mathrm{~d}, \mathrm{BCF}$ was almost constant except when the growth of $C$. pyrenoidosa and $C$. lunula approached to the stationary growth stages, where an increase in BCF occurred (Figs. 3 and 6).

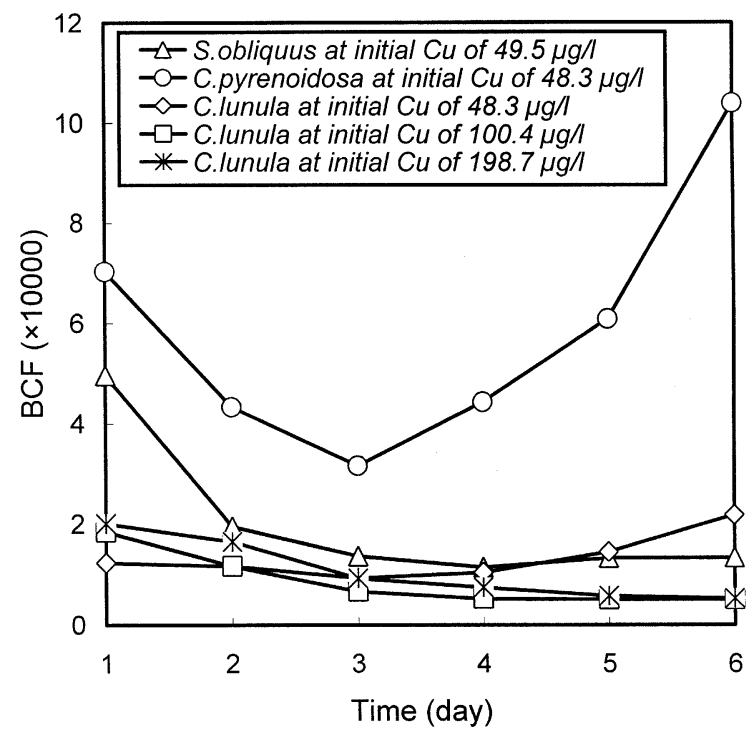

Fig. 6. The change of $\mathrm{BCF}$ of $\mathrm{Cu}$. $\mathrm{BCF}$ was the ratio between the accumulation amount of copper by microalgae and the level of $\mathrm{Cu}$ in the medium at different time intervals. 


\section{Discussion and conclusion}

\subsection{Relationship between toxicity and accumulation amount}

C. lunula was the most tolerant to $\mathrm{Cu}$ (Figs. 1 and 2), which accumulated the least $\mathrm{Cu}$ among the three microalgae studied especially in $1 \mathrm{~d}$ (Fig. 5). The great initial adsorption of $\mathrm{Cu}$ may cause serious damage to the algal cells, which may be responsible for the lower values of 96 h EC50 and greater sensitivities of C. pyrenoisosa and $S$. obliquus. However less accumulated $\mathrm{Cu}$ at similar initial $\mathrm{Cu}$ levels did not damage $C$. lunula because of its ability to exclude $\mathrm{Cu}$. It was reported that the tolerance of Dunaliella to heavy metals was due to its lesser uptake of heavy metals (Gimmler et al., 1991). Enteromorpha, which is frequently used as an indicator species for heavy metal contamination, contained relatively great concentration of $\mathrm{Cu}$ (Rijstenbil et al., 1998a,b). The chelation removal of heavy metals from the cell surface after the binding of $\mathrm{Cu}$ with organic complexes (including cell exudates) is another possible mechanism for the detoxification of metal ions (Xue et al., 1988; Xue and Sigg, 1990; Rijstenbil et al., 1994; Gerringa et al., 1995).

The tolerance of $C$. lunula to $\mathrm{Cu}$ may be due to physiology. When the initial $\mathrm{Cu}$ level was $198.7 \mu \mathrm{g} / \mathrm{l}$, the amount of $\mathrm{Cu}$ accumulated by $C$. lunula was greater than that of $C$. pyrenoidosa or $S$. obliquus exposed to 50 $\mu \mathrm{g} \mathrm{Cu} / \mathrm{l}$ (Fig. 5). However, its growth was not significantly inhibited (Fig. 3), indicating that $C$. lunula may have other mechanisms to detoxify $\mathrm{Cu}$. It has been reported that production of glutathione and other thiols as the copper-complexing ligands were promoted by algae under the stress of accumulated $\mathrm{Cu}$ (Rijstenbil and Wijnholds, 1996; Leal et al., 1999). SOD, providing antioxidant protection in algae, increased during the first day of exposure to $\mathrm{Cu}$ (Okamoto and Colepicolo, 1998).

\subsection{Accumulation amount of $\mathrm{Cu}$}

Smaller cells have relatively greater surface area and more sites for binding metals than those of larger cells, so accumulation amount of $\mathrm{Cu}$ in smaller cells are generally greater than those in larger cells (Khoshmanesh et al., 1997). Our results supported this conclusion where accumulation of $\mathrm{Cu}$ by algae was less in larger cells (C. pyrenoidosa $>$ S. obliquus $>$ C. lunula; Figs. 4-6).

\subsection{Accumulation kinetics}

The long-term accumulation of $\mathrm{Cu}$ by microalgae depends on the processes of the fast passive adsorption, slow active uptake and desorption (Kuyucak and Volesky, 1989; Knauer et al., 1997). The fast passive adsorption was responsible for the first peaks of both accumulation amount and $\mathrm{BCF}$ of $\mathrm{Cu}$ by microalgae at day 1 (Figs. 5 and 6). Accumulation of $\mathrm{Cu}$ by microalgae was diluted by the rapid growth of microalgae. The stress of $\mathrm{Cu}$ absorbed by microalgae can stimulate the secretion of organic ligands that can bind and exclude heavy metal ions from cells, which may contribute to the decrease of $\mathrm{BCF}$ during the exponential growth phase (Fig. 6). The increase of BCF during the stationary growth phase may be due to the death of algal cells, which were losing active desorption abilities. Dead algal cells can uptake more metals than living cells because of the losing the desorption ability of metals (Hassall, 1962). Since the growth of $S$. obliquus was more sensitive to $\mathrm{Cu}$ (Figs. 1 and 2), the time for reaching exponential growth phase and the minimum BCF was delayed (Figs. 3 and 6). Desorption ability of microalgae was tightly related to the growth phase of microalgae. $\mathrm{pH}$ of medium slightly increased from initial 7.0 to about 8.0 during the 6-d period, which caused the change of $\mathrm{Cu}$ speciation.

Growth rate is a dominant factor to determine the biodegradation of organic compound by $C$. pyrenoidosa (Yan et al., 1995). Our finding indicated that the growth phase also played an important role in determining active desorption ability of $\mathrm{Cu}$ by microalgae. The results presented here can explain why $\mathrm{Cu}$ accumulation was less during the spring or summer but greater in the autumn or winter (Leivuori and Vallius, 1998). The exponential growth of microalgae generally appeared in the spring or summer. In short-term, the adsorption equilibrium of metals by microalgae followed the Freundlich or Langmuir isotherm. But for long-term exposure, a different model needs to be studied to fit the accumulation data.

\subsection{Conclusion}

(1) C. lunula was the most tolerant while $S$. obliquus most sensitive to $\mathrm{Cu}$. Lesser initial accumulation of $\mathrm{Cu}$ might be responsible for a greater tolerance of microalgae to $\mathrm{Cu}$. (2) Three microalgal species tested were able to desorb more $\mathrm{Cu}$ during the exponential growth phase but less in the stationary growth phase. (3) Microalgae with smaller cell volume but greater sensitivity to $\mathrm{Cu}$ are recommended for the efficient removal of $\mathrm{Cu}$ from wastewater.

\section{Acknowledgements}

The research was funded by Chinese NNSF grant no. 39870133. The work was also supported by Chinese NNSF grant no. 20073060. The authors thank Mr. Wei Zhang for his assistance in the determination of $\mathrm{Cu}$. Comments of an anonymous reviewer are greatly appreciated. 


\section{References}

Brown, L.N., Robinson, M.G., Hall, B.D., 1988. Mechanisms of copper tolerance in Amphora coffeaeformis internal and external binding. Mar. Biol. 97, 581-586.

Chang, C., Sibley, T.H., 1993. Accumulation and transfer of copper by Oocystis pusilla. Bull. Environ. Contam. Toxicol. 50, 689-695.

Chinese EPA, 1989. Standard Analytic Methods for the Examination of Water and Wastewater. Chinese Environmental Science Publisher, Beijing, China (in Chinese).

Gerringa, L.J.A., Rijstenbil, J.W., Poortvliet, T.C.W., Van Drie, J., Schot, M.C., 1995. Speciation of copper and response of the marine diatom Ditylum brightwellii upon increasing copper concentrations. Aquat. Toxicol. 31, 7790.

Gimmler, H., Treffny, B., Kowalsky, M., Zimmermann, U., 1991. The resistance of Dunaliella acidophila against heavy metals: The importance of the zeta potential. J. Plant. Physiol. 138, 708-716.

Hassall, K.A., 1962. A specific effect of copper on the respiration of Chlorella vulgaris. Nature 193, 90.

Hornstrom, E., 1990. Toxicity test with algae-A discussion on the batch method. Ecotoxicol. Environ. Safety 20, 343-353.

Khoshmanesh, A., Lawson, F., Prince, I.G., 1997. Cell surface area as a major parameter in the uptake of cadmium by unicellular green microalgae. Chem. Eng. J. 1, 13-19.

Knauer, K., Behra, R., Sigg, L., 1997. Effects of free $\mathrm{Cu}^{2+}$ and $\mathrm{Zn}^{2+}$ ions on growth and metal accumulation in fresh-water algae. Environ. Toxicol. Chem. 16 (2), 220-229.

Kuyucak, N., Volesky, B., 1989. The mechanism of cobalt biosorption. Biotech. Bioeng. 33, 823-831.

Leal, M.F.C., Vasconcelos, M.T.S.D., Berg, C.M.G., 1999. Copper-induced release of complexing ligands similar to thiols by Emiliania huxleyi in seawater cultures. Limnol. Oceanogr. 7, 1750-1762.

Leivuori, M., Vallius, H., 1998. A case study of seasonalvariation in the chemical-composition of accumulating suspended sediments in the central Gulf-of-Finland. Chemosphere 3, 503-521.

Okamoto, O.K., Colepicolo, P., 1998. Response of superoxidedismute to pollutant metal stress in the marine dinoflagellate Gonyaulax-polyedra. Comparative Biochem. Physiol. CPharmacol. Toxicol. Endocrinol. 1, 67-73.
Nassiri, Y., Mansot, J.L., Wery, J., Ginsburger-Vogel, T., Amiard, J.C., 1997. Ultrastructural and electron energy loss spectroscopy studies of sequestration mechanisms of $\mathrm{Cd}$ and $\mathrm{Cu}$ in the marine diatom Skeletonema costatum. Arch. Environ. Contam. Toxicol. 33, 147-155.

Rijstenbil, J.W., Wijnholds, J.A., 1996. HPLC analysis of nonprotein thiols in planktonic diatoms: pool size, redox state and response to copper and cadmium exposure. Mar. Biol. 127, 45-54.

Rijstenbil, J.W., Derksen, J.W.M., Gerringa, L.J.A., Poortvliet, T.C.W., Sandee, A., Van den Berg, M., Van Drie, J., Wijnholds, J.A., 1994. Oxidative stress induced by copper: defense and damage in the marine planktonic diatom Ditylum brightwellii (Grunow) West, grown in continuous cultures with high and low zinc levels. Mar. Biol. 119, 583590.

Rijstenbil, J.W., Dehairs, F., Ehrlich, R., Wijnholds, J.A., 1998a. Effect of the nitrogen status on copper accumulation and pools of metal-binding peptides in the planktonic diatom Thalassiosira pseudonana. Aquat. Toxicol. 42, 187209.

Rijstenbil, J.W., Haritonidis, S., Malea, P., Seferlis, M., Wijnholds, J.A., 1998b. Thiol pools and glutathione redox ratios as possible indicators of copper toxicity in the green macroalgae Enteromorpha spp. from the Scheldt Estuary (SW Netherlands, Belgium) and Thermaikos Gulf (Greece, N. Aegean Sea). Hydrobiologia. 385, 171-181.

Soldo, D., Behra, R., 2000. Long-term effects of copper on the structure of fresh water periphyton communities and tolerance to copper, zinc, nickel and silver. Aquat. Toxicol. 47, 181-189.

Xue, H.B., Sigg, L., 1990. Binding of $\mathrm{Cu}(\mathrm{II})$ to algae in a metal buffer. Water Res. 24, 1129-1136.

Xue, H.B., Stumm, W., Sigg, L., 1988. The binding of heavy metals to algal surfaces. Water Res. 22 (7), 917-926.

Yan, H., Ye, C.M., Yin, C.Q., 1995. Kinetics of phthalate ester biodegradation by Chlorella pyrenoidosa. Environ. Toxicol. Chem. 14 (6), 931-938.

Yu, Q., Matheickal, J.T., Yin, P., Kaewsarn, P., 1999. Heavy metal uptake capacities of common marine macro algal biomass. Water Res. 33 (6), 1534-1537.

Zhou, Y., Zhang, Z., 1989. Standard Methods of Hydrobiology Bioassay for Evaluating the Toxicity of Toxic Chemicals. Agriculture publisher, Beijing, China (in Chinese). 